\title{
CALIFORNIA ENERGY FLOW IN 1992
}

\author{
I. Y. Borg \\ C. K. Briggs
}

April 1, 1994

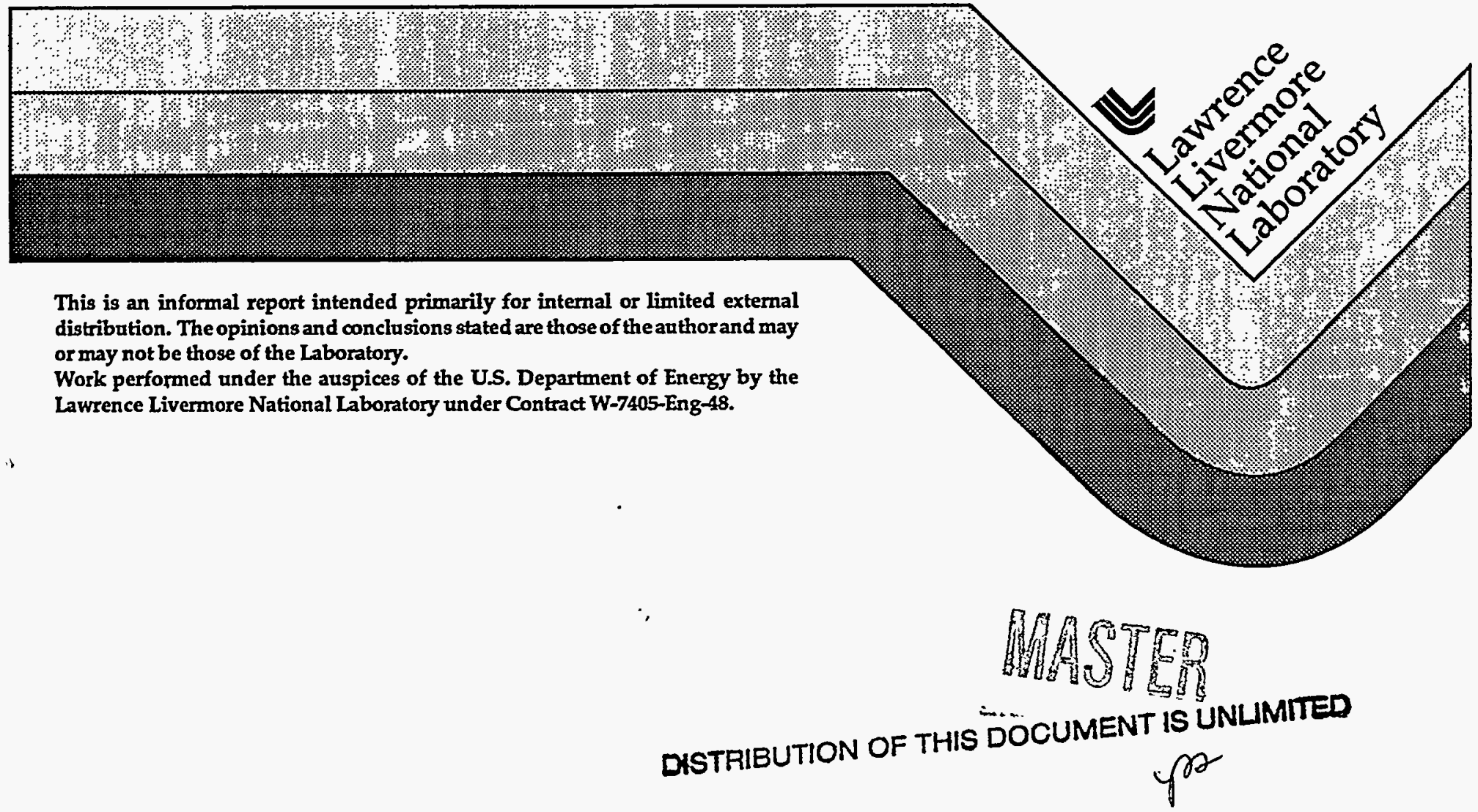




\section{DISCLAIMER}

This document was prepared as an account of work sponsored by an agency of the United States Government. Neither the United States Government nor the University of California nor any of their employees, makes any warranty, express or implied, or assumes any legal liability or responsibility for the accuracy, completeness, or usefulness of any information, apparatus, product, or process disclosed, or represents that its use would not infringe privately owned rights. Reference herein to any specific commercial products, process, or service by trade name, trademark, manufacturer, or otherwise, does not necessarily constitute or imply its endorsement, recommendation, or favoring by the United States Government or the University of California. The views and opinions of authors expressed herein do not necessarily state or reflect those of the United States Government or the University of California, and shall not be used for advertising or product endorsement purposes.

This report has been reproduced directly from the best available copy.

Available to DOE and DOE contractors from the Office of Scientific and Technical Information P.O. Box 62, Oak Ridge, TN 37831

Prices available from (615) 576-8401, FTS 626-8401

Available to the public from the National Technical Information Service

U.S. Department of Commerce 5285 Port Royal Rd., Springfield, VA 22161 


\section{DISCLAIMER}

Portions of this document may be illegible in electronic image products. Images are produced from the best available original document. 


\section{CONTENTS}

Page

$\begin{array}{lr}\text { ABSTRACT } & 1\end{array}$

INTRODUCTION 2

CALIFORNIA ENERGY FLOW DIAGRAMS 2

CALIFORNIA'S ENERGY FLOW IN 1992 COMPARED TO 1991

TRANSPORTATION FUELS 10

OIL AND GAS PRODUCTION

NATURAL GAS SUPPLY 13

ELECTRIC POWER 14

Source of Supply $\quad 14$

Alternate Sources of Electricity 16

Geothermal power 16

$\begin{array}{ll}\text { Solar electricity } & 16\end{array}$

Windpower 17

APPENDIX A Energy balance for $1992 \quad 19$

APPENDIX B Data Sources for California Energy Supply - $1992 \quad 20$

APPENDIX C Data Sources for California End Uses - 1992

APPENDIX D Conversion Units and Assumed Conversion Efficiencies 23

$\begin{array}{ll}\text { REFERENCES } & 24\end{array}$ 


\section{ABSTRACT}

In 1992 energy consumption in California moved up slightly despite a continuing statewide recession marked by an unemployment rate of almost $10 \%$ at year's end. Nonetheless industrial energy consumption increased reflecting increased use of fossil fuels in enhanced oil recovery and cogeneration. A small drop in residential/commercial energy consumption related to an uncommonly mild winter. Energy use in the transportation sector declined for the second year reflecting most importantly a $30 \%$ decline in the sale of bunkering fuels at California ports due to the imposition of new taxes in 1991 and a 2\% fall in gasoline sales between 1991 and 1992.

Oil production in the State remained at 1990-1991 levels. Increased federal offshore production notably at the Point Arguello field countered declines in onshore areas. Gas production fell, and an increased demand was satisfied by greater imports from the Southwest U.S., Rocky Mountain area and Canada. Gas pipeline construction continued at a record pace with the completion of five pipelines into the state.

Electricity demand increased and was met by increased generation from natural gas made possible by the pipeline completions and by greater output from the State's nuclear power plants. The latter occurred despite the retirement of the State's oldest nuclear reactor, San Onofre Unit 1 (436 MWe) in San Diego County. Collective electricity generated at California's many geothermal fields remained at the previous year's level although output at The Geysers, the world's largest field continued to decline. Contributions from windpower to electrical demand fell for the first time since 1983 due in part to expiration of long-term, "standard offer" contracts with favorable rates that had been negotiated with the utilities purchasing the power. Electricity from windpower made up a little more than $1 \%$ of power transmitted by the utilities to users. Solar energy's contribution to the energy slate is largely in the form of hot water and is not accurately monitored. The only sizable solar electrical installations are experimental in nature and make a negligible contribution. 


\section{INTRODUCTION}

For the past 16 years energy flow diagrams for the State of California have been prepared from available data by members of the Lawrence Livermore National Laboratory. ${ }^{1}$ They have proven to be useful tools in graphically expressing energy supply and use in the State as well as illustrating the difference between particular years and between the State and the U.S. as a whole.

As far as is possible, similar data sources have been used to prepare the diagrams from year to year and identical assumptions ${ }^{1 \mathrm{a}-1 \mathrm{e}}$ concerning conversion efficiencies have been made in order to minimize inconsistencies in the data and analyses. Sources of data used in this report are given in Appendix B and C; unavoidably the sources used over the 1976-1993 period have varied as some data bases are no longer available. In addition, we continue to see differences in specific data reported by different agencies for a given year. In particular, reported data on supply and usage in industrial/commercial/residential end-use categories have shown variability amongst the data gathering agencies, which bars detailed comparisons from year to year. Nonetheless, taken overall, valid generalizations can be made concerning gross trends and changes.

\section{CALIFORNIA ENERGY FLOW DIAGRAMS}

California energy flow diagrams for 1992 and 1991 are shown in Figs. 1 and 2, respectively. For comparison the U.S. energy flow for $1992^{2}$ is shown in Fig. 3. Energy sources are shown on the left and energy consumption is shown on the right. The energy balance between the two is given in Appendix A. Also shown on the right are estimates of conversion efficiencies in the end-use sector, which result in a division between useful and rejected energy. The latter consists primarily of heat losses. Conversion and plant losses at electric utility generation stations burning fossil fuels are a matter of record, but inputs to total transmitted electricity such as nuclear, geothermal power, etc., are associated with estimated efficiencies of the conversion process to electricity. They vary from $90 \%$ in the case of hydroelectric power to $18 \%$ for geothermal energy. Assumptions concerning the conversion efficiencies are given in Appendix D, and their rationale can be found in Refs. $1 \mathrm{~b}$ and $1 \mathrm{c}$. The box separating the energy source from the final electrical output represents the conversion process. In all cases the quantities associated with the energy source are calculated based on the assumed conversion efficiencies. While it is desirable to minimize the number of assumptions in preparing an energy flow diagram, it is also 


\section{CALIFORNIA ENERGY FLOW -1992 TOTAL CONSUMPTION $6900 \times 10^{12} \mathrm{Btu}$}

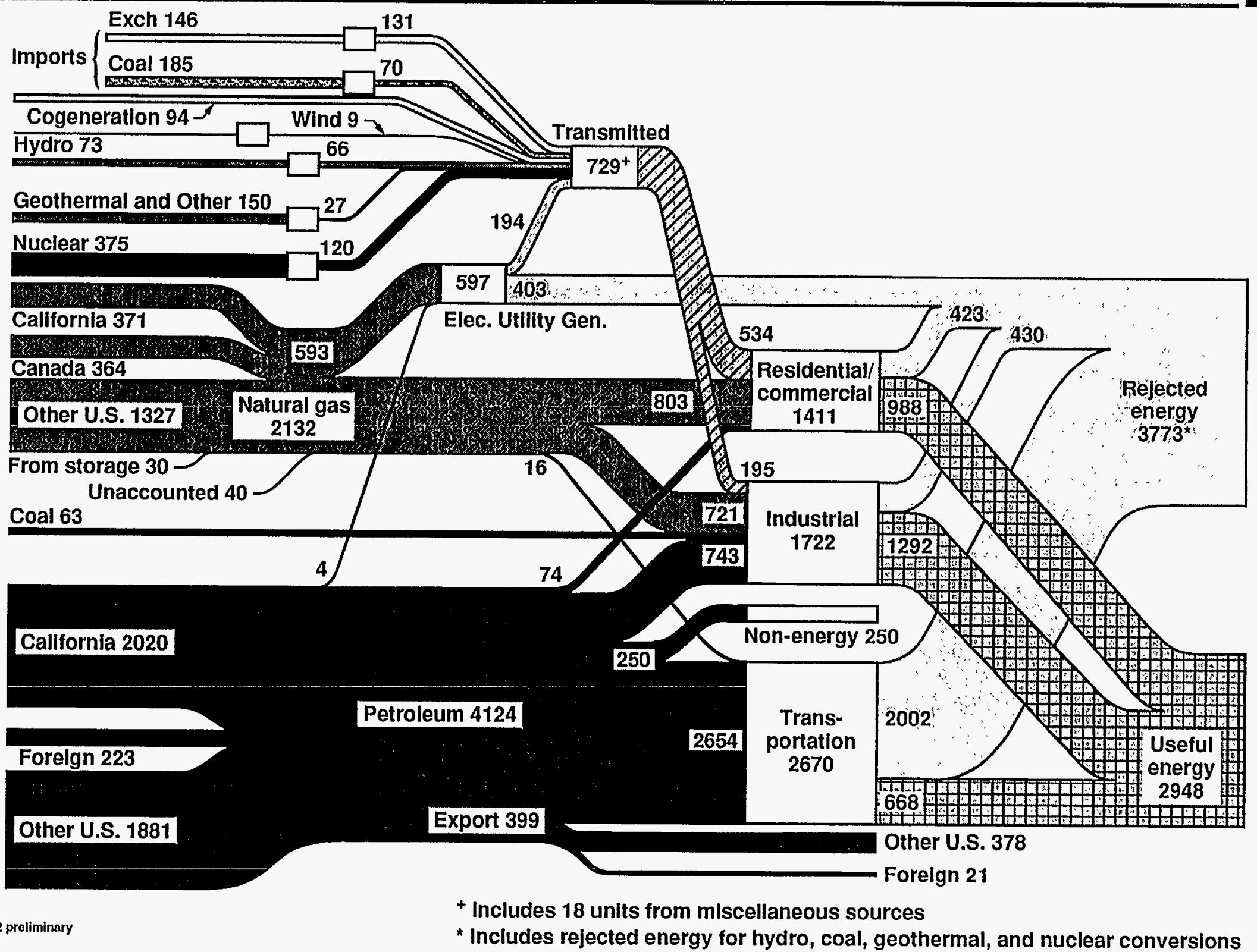




\section{CALIFORNIA ENERGY FLOW -1991 TOTAL CONSUMPTION $6800 \times 10^{12} \mathrm{Btu}$}

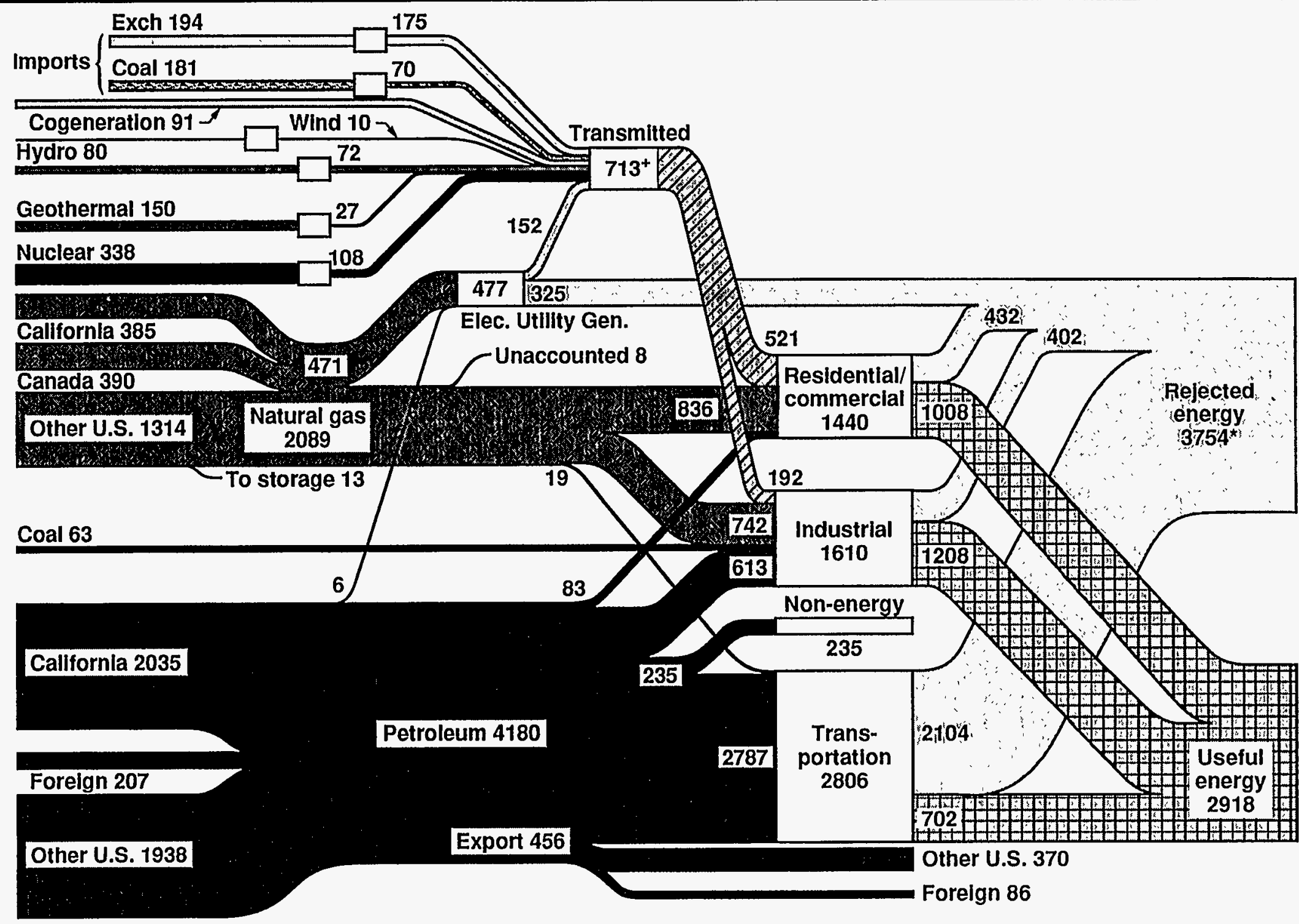

+ Includes 8 units from miscellaneous sources

* Includes rejected energy for hydro, coal, geothermal, and nuclear conversions 


\section{U.S. Energy Flow - 1992 \\ Net Primary Resource Consumption 82 Quads}

Net imports 0.3

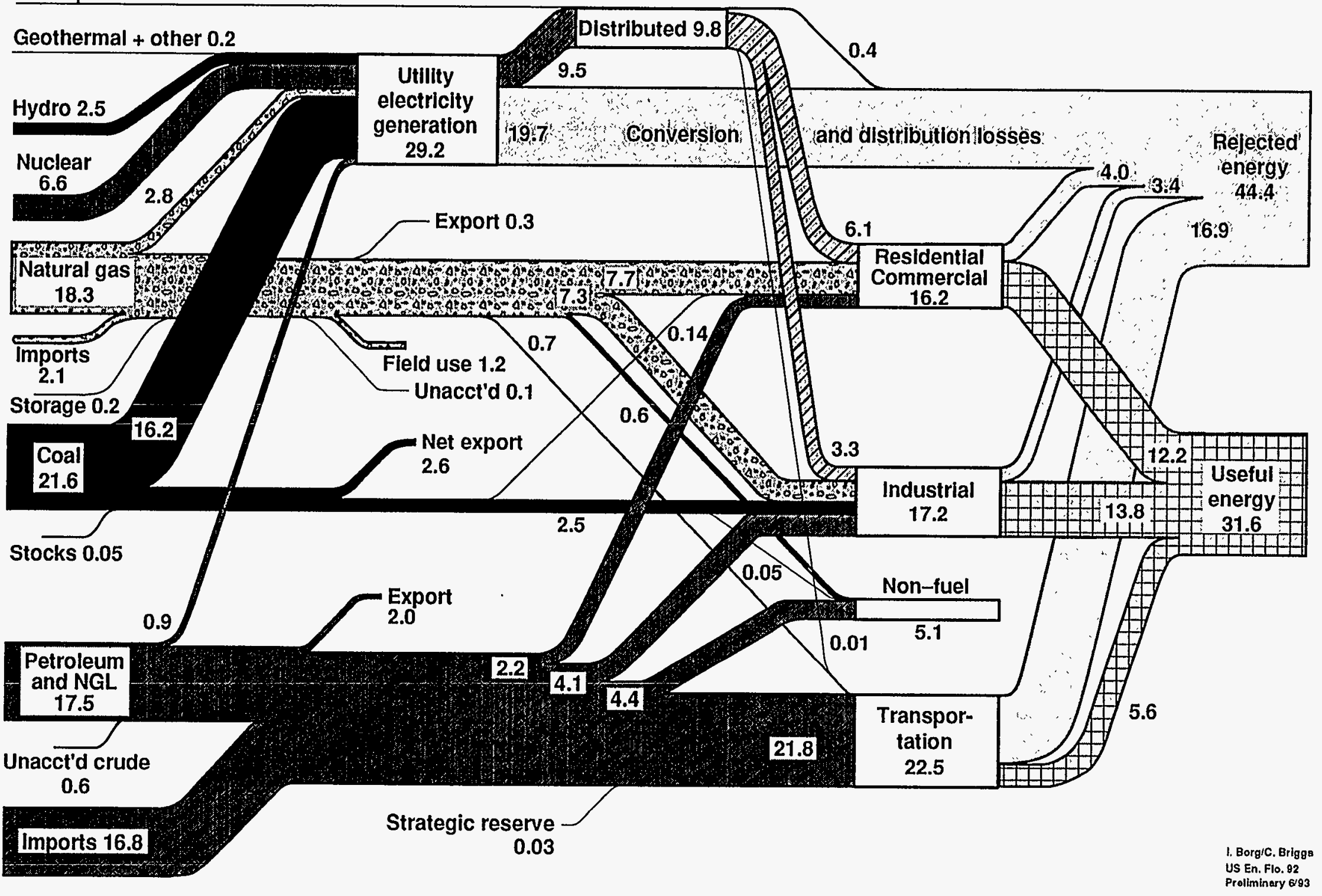


desirable to express as closely as possible the energy content of the sources used during the year. In this way it is possible to see at a glance which energy sectors are associated with the greatest conversion losses and thus the largest targets for potential technological improvements in conversion efficiencies.

Power from cogenerators and self-generators sold to utilities are shown in the figures as inputs to total transmitted electricity and appear without a box (representing the conversion process) that ordinarily would appear between the energy content of the fuel and the final product. In this instance, conversion losses are included in "rejected energy" from the industrial sector. Not shown in the flow diagrams is the amount of electricity used "in house" by the cogenerators. The amount of electricity consumed by the industrial sector, $195 \times 10^{12}$ Btu in Fig. 1, represents purchases from the utilities only.

\section{CALIFORNIA'S ENERGY FLOW IN 1992 COMPARED TO 1991}

\section{The Economy}

While the economy of the nation apart from California showed signs of recovery from the worst recession since the 1930's, California's economy continued to decline in 1992 (Table 1). Most noteworthy was the unemployment rate that stood at $9.8 \%$ at year's end as compared to $6.9 \%$ for the rest of the nation. ${ }^{3}$ This is in marked contrast to California's economic performance between the end of World War II and 1989 when it consistently out performed the rest of the nation. Explanations for change include continued cutbacks in defense expenditures in the State, the five year drought, tax increases and state expenditure cutbacks and over expansion of the commercial construction industry. ${ }^{4}$ Unique impacts on California's economy in 1992 include a

\section{Table 1.}

$\begin{array}{lc}\text { Indicator } & \text { Selected economic data for California }-1992^{5} \\ \text { Unemployment } & \text { Percent change from 1991 } \\ \text { Civilian employment } & +23.1 \\ \text { Housing units authorized } & 0.6 \\ \text { New auto registrations } & -9.9 \\ \text { Total taxable sales } & -6.7 \\ \text { Corporate profits before taxes } & 0.8 \\ \text { Personal income } & +8.2 \\ \text { Consumer price index } & +2.6 \\ \end{array}$


series of large earthquakes (Palm Springs in April, Ferndale in April and Yucca Valley/Big Bear in June) and the Los Angeles riots at the end of April, which were all disruptive of normal economic activity.

The construction industry continued to languish (Table 2) as evidenced by the decrease for the fourth year in the number of authorizations for construction of new multiple residential, commercial and industrial units. The situation would be worse if it were not for the rebuilding in the San Francisco Bay Area following the Montclair district fire in 1991 and Loma Prieta earthquake in 1989.

Table 2

Construction authorized by permit $=1992^{6}$

Value in Millions of Dollars

\begin{tabular}{llll} 
Year & Residential & \multicolumn{2}{c}{ Nonresidential } \\
& & Commercial & Other* \\
1988 & 26,361 & 6,569 & 7,592 \\
1989 & 27,790 & 6,159 & 7,507 \\
1990 & 20,686 & 5,270 & 7,466 \\
1991 & 15,056 & 3,374 & 6,247 \\
1992 & 14,451 & 2,472 & 5,683
\end{tabular}

*Other consists of all other categories including additions and alterations of $\$ 100,000$ or more.

\section{Energy Consumption}

Use of energy in California for the preceding decade is summarized in Table 3. In 1992 crude oil continued to be the principal source of supply with about half of it coming from out-ofstate sources. Demand was close to 1991 levels. Natural gas was the next most important fuel with more than three-quarters of the supply being imported. Use rose slightly in 1992 principally because of increased use for utility electricity generation. However the largest single source of transmitted electricity was imports from other states.

There was a small drop in residential/commercial energy use which relates to an uncommonly mild winter experienced in all parts of the state (Table 4). Although electricity use rose slightly, it was more than compensated by a decrease in consumption of natural gas, the principal fuel used for space heating. Industrial activity as measured by energy consumption increased in 1992 as did the "non-energy" component. The "non-energy" component of industrial 
Table 3

Comparison of Annual Energy Use in California

$$
\text { (in } 10^{12} \mathrm{Btu} \text { ) }
$$

\begin{tabular}{lllllllllll}
1982 & 1983 & 1984 & 1985 & 1986 & 1987 & 1988 & 1989 & 1990 & 1991 & 1992 \\
\hline
\end{tabular}

$\begin{array}{lrrrrrrrrrrr}\text { Natural Gas } & 893 & 1769 & 1865 & 2034 & 1697 & 2091 & 1932 & 2087 & 2069 & 2089 & 2132 \\ \text { Crude Oil (less exports) } & 3327 & 3329 & 3477 & 3580 & 3601 & 3591 & 3899 & 4015 & 3884 & 3736 & 3725 \\ \text { Transmitted Electricity } & 642 & 622 & 700 & 673 & 697 & 718 & 744 & 757 & 763 & 713 & 729 \\ \text { Residential/Commercial } & 1225 & 1268 & 1176 & 1325 & 1224 & 1325 & 1350 & 1403 & 1474 & 1442 & 1411 \\ \text { Industrial } & 1570 & 1395 & 1493 & 1648 & 1456 & 1439 & 1557 & 1646 & 1560 & 1616 & 1722 \\ \text { Non-energy } & 158 & 183 & 221 & 185 & 203 & 292 & 235 & 237 & 252 & 245 & 250 \\ \text { Transportation } & 2265 & 2313 & 2464 & 2384 & 2499 & 2564 & 2715 & 2781 & 2817 & 2800 & 2670 \\ & & & & & & & & & & & \\ \text { Total Energy Consumption } \dagger & 6000 & 5900 & 6200 & 6400 & 6200 & 6600 & 6750 & 6950 & 6900 & 6800 & 6900\end{array}$

$\dagger$ Total is not sum of above figures because of rounding and inclusion of losses associated with conversion to electrical energy. 
Table 4

Weather Comparison

1968 - 1992

Annual Heating Degree Days**

\section{San Francisco \\ Federal Office \\ Building}

1968

1969

1970

1971

1972

1973

1974

1975

1976

1977

1978

1979

1980

1981

1982

1983

1984

1985

1986

1987

1988

1989

1990

1991

1992

Normal

1951-80
2942

3066

3006

3468

3240

3161

3182

3313

2665

2888

2599

2545

2799

2819

3195

2386

2648*

2486*

$1842 *$

2150*

2194*

$2526 *$

2340*

2422*

1718

$2750 * * *$
Los Angeles
Civic Center

850

1032

941

1424

918

1066

1084

1548

1128

911

1208

1160

597

506

975

602

704

921

473

979

867

844

839

879

705

1204
San Diego

Lindbergh

Field

1052

1145

1137

1657

1166

1137

1123

1416

793

747

736

902

590

573

913

623

713

1079

843

1201

1102

1068

1172

1212

866

1284

* CA. Mission Dolores same historical data as for Federal Office Building

Source: Local Climatological Data for San Francisco, Los Angeles and San Diego, National Oceanic and Atmospheric Admin., National Climatic Data, Asheville, NC.

** A "degree day" is a term that describes the relationship of energy consumption to outdoor temperatures. "Heating or cooling degree days" are deviations of the mean daily temperature from $65^{\circ} \mathrm{F}$. For example for a day with a mean temperature of $40^{\circ} \mathrm{F}$, the "heating degree days" would be 25 and the "cooling degree days" 0 . Annual heating degree days are the sum for the year. Greater number of heating degree days means greater fuel requirements.

*** Revised by W. J. Koss, NOAA, September 7, 1988. 
consumption consists of fuels used to produce products such as petrochemicals, fertilizers, waxes, lubricating oils, asphalt etc. These products are not burned to produce energy.

\section{TRANSPORTATION FUELS}

\section{Consumption}

Transportation use of fossil fuels fell substantially for the first time in seven years (Table 3). The decrease can be traced to (1) continued and marked drop in sales of bunkering fuels at California ports and (2) a drop in gasoline consumption (Table 5). Sales of bunkering fuels have been affected by new taxes imposed in mid-1991. The decline in gasoline sales is a reflection on improved fuel economy of highway vehicles and the recession, which hampered commercial business activity and reduced the number of registered commercial vehicles. ${ }^{7}$ Nonetheless the estimated vehicle miles of travel on California State highways rose $1.44 \%$ and 75,000 new drivers

Table 5

California Transportation End Use

$$
\text { (in } 10^{12} \mathrm{Btu} \text { ) }
$$

$\begin{array}{rrrrrrr}1986 & 1987 & 1988 & 1989 & 1990 & 1991 & 1992 \\ 1543 & 1576 & 1612 & 1630 & 1664 & 1712 & 1670 \\ 392 & 390 & 427 & 458 & 475 & 476 & 473 \\ 218 & 174 & 244 & 265 & 253 & 246 & 256 \\ & & & & & & \\ 31 & 30 & 26 & 30 & 31 & 33 & 30 \\ 267 & 347 & 357 & 348 & 344 & 288 & 202 \\ 35 & 28 & 29 & 30 & 29 & 26 & 23 \\ 15 & 13 & 20 & 20 & 21 & 19 & 16\end{array}$

Natural gas-pipeline fuel

Natural gas vehicular Total**

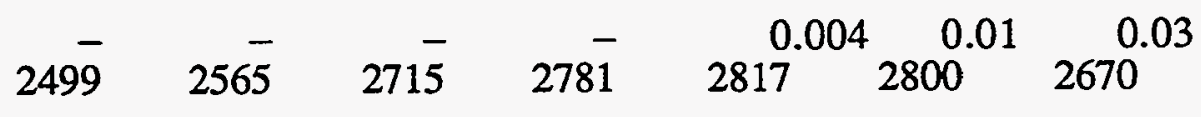

* As of January 1, 1992 leaded gas was no longer produced at California refineries.

** Some electricity is used for mass transit; however the amount is not monitored on a state-wide basis and hence does not appear in this table or in Figs. 1 and 2.

Source: Fuel and Kerosene Sales, DOE/EIA, 1992; Quarterly Oil Report. Fourth Quarter 92 (Net gasoline and aviation fuel), California Energy Commission, Sacramento, CA; Natural Gas Annual1992, DOE/EIA-0131(92) Table 48, Department of Energy, Washington, DC (November 1993).

licenses were issued. ${ }^{7}$ Intercity bus travel was down for the third straight year as was transit patronage reported by the 11 major transit operators in the state. Intercity and commuter rail systems reported mixed results for the year. 


\section{Automobile Emission Standards}

The California Air Resources Board (CARB) has set the toughest regulations in the nation under the Clean Air Act of 1970 and its amendments. The act restricted the independent action of all states without Environmental Protection Agency's (EPA) approval. Because California had an active emission abatement program, it was able to continue to write its own rules; however, for the first time since the passage of the Act, it had to have permission to enforce them. Applications to the EPA for the so-called "waivers" have been met with little opposition through the years and led to now common items as catalytic converters and no-lead gasoline requirements ultimately applied nationally by EPA.

In 1992 for the first time EPA looked hard at some of the regulations passed by CARB in 1990. ${ }^{8}$ In particular, the Low-Emission Vehicle Program, which proposes that 1994 to 2003 models run 60-85\% cleaner than current models and that 2-10\% be "zero polluting" between 1998 and 2003, has come under attack from both car manufacturers and refiners. Strangely, the problem is that other states have either already adopted the program or are about to. While California represents only about a tenth of the nation's car market, a program embracing many states could seriously impact the nation's ailing car industry. A General Motors spokesman claimed that the company might survive having to recall every car built in California for failing to meet emission requirements, but it could not survive a national recall. Both the car manufacturers and refiners point out that severe air pollution is California's problem and not that of every state. They point out that pollution in the State is driven by a car population that is growing twice as fast as its human population. ${ }^{9}$ Further the oldest cars in the nation use its highways. Nearly one-third are pre-1979 models which are heavy air polluters. ${ }^{8}$ Old cars may account for only about a fifth of the miles driven in the state but nearly $60 \%$ of the hydrocarbons and about half of the carbon monoxide and nitrogen oxides according to CARB. Hence they suggest among other things a more aggressive program to maintain and/or retire this old fleet of vehicles.

Because California has indicated that it wants 2\% of new cars sold in the state in 1998 to be non-polluting and because at least nine other states have said they will concur, all auto makers have embarked on programs to develop electric vehicles. In addition, a consortium of public and private California interests called Calstart unveiled a prototype in 1992. To some an electric car industry in California would be a suitable substitute for the declining defense and aerospace industries of the State. This remains wishful thinking until technical "break-throughs" in battery or fuel cell technology are realized. Because the current vehicles have limited range, they are believed to have little customer appeal. Assuming gasoline prices do not escalate to high levels in the next decade, it is likely that the consumer rather than the regulator will decide the issue in the long run. In the meantime several public utilities and public agencies are taking appropriate steps to assist the hoped for transition to non polluting vehicles. For example, through the decisions of the California Public 
Utilities Commission, legislative mandates, and utility initiatives, $\$ 50$ million for "low emission vehicle" research and activities is paid annually by California utility rate payers. ${ }^{10}$

\section{OIL AND GAS PRODUCTION}

\section{Qil Production}

California oil production remained at 1990 and 1991 levels and thus was down about $18 \%$ from the all time high recorded in $1985 .{ }^{11}$ Declines registered in state onshore and offshore fields were compensated by an increase in federal offshore production. Again the Midway-Sunset oil field was the largest producing field in the U.S. outside of Alaska. It reached its all-time high production rate in June 1992; its cumulative production over its 100 year lifetime is well over two billion barrels.

Enhanced oil recovery accounted for about $61 \%$ of California's total oil production. ${ }^{11}$ Steam stimulation was credited with about $80 \%$ of all incremental oil production and water flooding the remainder.

The number of new oil, gas, service and exploratory wells drilled onshore or in California offshore provinces fell $46 \%$ in $1992 . .^{11}$ The 1212 wells drilled are about a third of the all time high recorded in 1985 and somewhat below 1960 totals.

A ten year dispute between Chevron and officials of Santa Barbara County concerning the way to move crude oil from the Point Arguello offshore field to shore, reached an interim resolution. Santa Barbara officials' concern centered on potential oil spills from tankers. Heretofore most of the production was piped to Chevron's Northern California refinery where it was loaded onto tankers destined for Southern California-ironically transiting the Santa Barbara County coast line. Limited pipeline capacity had curtailed production at the field. The compromise calls for crude not accommodated by existing pipelines to be tankered directly to Southern California refineries. ${ }^{12}$ The tankering must end by January 1996 when construction of additional pipelines are completed. The consequence of the compromise was that output from the field increased from 65,00 barrels a day to 90,000 barrels a day making it the largest producer in both state and federal waters off California.

Ten companies shipping oil from Alaska to California ports agreed to stay at least 50 nautical miles from the California mainland. ${ }^{13}$ As almost all of California's imported oil comes from Alaska (Fig. 1) about $85 \%$ of all arriving oil tankers will be covered by the voluntary agreement. The 50 mile minimum distance was arrived at after a review of studies of oil spills, present vessel routes and consultation with California's Department of Fish and Game's Office of Oil Spill Prevention and Response. 
As another indication of continued concern over oil spills in offshore provinces, Governor Wilson signed legislation banning offshore drilling in state waters from San Simeon to the Oregon border. ${ }^{14}$ Together with Presidents Bush's ban on oil and gas lease sales in federal waters off California, Governor Wilson's action effectively bans further activity until after 1995. Similar bans are already in place in the southern part of the state.

\section{Natural Gas Production}

Gas production fell $8 \%$ from 1991 levels with the greatest decrease registered by so called "non associated" wells, i.e. wells not associated with oil production. ${ }^{11}$ Natural gas production in the state is divided approximately equally between the two types of wells with "associated" production occurring predominantly in the southern part of the State and "non associated" production in the northern.

\section{NATURAL GAS SUPPLY}

Natural gas production in the State has fallen to about half of its historic high of 1966-68. The decline and growing demand for the fuel has resulted in increased out-of-state imports. In 1992 they comprised $79 \%$ of demand $-62 \%$ from the Southwest U.S. and $17 \%$ from Canada (Fig. 1).

Gas pipeline construction in California continued at a record pace (Table 6) with the completion of five lines into the state from the Southwest U.S. or Rocky Mountain area. The Kern River Gas pipeline, the biggest built in the U.S. in the last decade, was dedicated in the Spring. The capacity of the 904 mile pipeline is currently $700 \mathrm{Mcf} / \mathrm{d}$, and it can be boosted $452 \mathrm{Mcf} / \mathrm{d}$ by adding compressors. ${ }^{15}$ The Kern River pipeline is California's only direct link to Rocky Mountain gas reserves. With the completion of Pacific Transmission Company's 805 mile line from Canada in November of 1993, pipeline capacity into the state will have increased $46 \%$ since $1990 .{ }^{16} \mathrm{~A}$ large part of the new capacity is directed to enhanced oil recovery operations in the heavy oil fields in Southern California where air quality regulations have made natural gas the only acceptable fuel to raise steam in underground steam flooding operations. This demand has led to a steady increase in industrial natural gas consumption in the State.

Table 6

Status of California Pipeline Proposals $1992^{16}$

\section{Project}

Completed or under construction

Proposed or pending

Total
Miles

2475

1013

3488
Capacity (Bcf/d)

3.143

2.606

5.749 
The second most important destination for the additional gas is electrical generating facilities belonging both to utilities and cogenerators. Again air quality considerations and high costs associated with nuclear power plants make natural gas the fuel of choice in new facilities.

For several years the California Public Utilities Commission has tried to force the state's utilities to buy natural gas from Canadian suppliers on short-term contracts in order to reduce costs to consumers. Heretofore the utilities have routinely paid a premium for the security of supply associated with long-term contracts. In 1992 the Canadian National Energy Board became concerned when California utilities began to negotiate short term contracts, and it stepped in by prohibiting new exports of natural gas to northern California. ${ }^{17}$ The intent was to pressure the utilities to meet their long-term contracts to buy natural gas instead of switching to cheaper short term supplies.

\section{ELECTRIC POWER}

\section{Source of Supply}

The most noteworthy change in California's electrical supply in 1992 was the increase in the use of natural gas for power production and the commensurate decrease in the amount of purchases from the Pacific Northwest (Table 7). New gas pipelines into the state are making such a switch possible. Also noteworthy was a $10 \%$ increase in the contribution made by nuclear power.

Total utility generating capacity (Table 8 ) was very near 1991's. There were small increases in natural gas, hydropower and alternative fuel capacity which together countered a decrease in nuclear capacity.

Table 7

\begin{tabular}{|c|c|c|}
\hline Source & $\frac{1992}{\text { Net }}$ & $\begin{array}{l}\text { energy } \\
\text { 3tu) }\end{array}$ \\
\hline Imports & & 201 \\
\hline Out-of-state coal facilities & 70 & \\
\hline $\begin{array}{l}\text { Purchases } \\
\text { Pcil fuelcs }\end{array}$ & 131 & \\
\hline $\begin{array}{l}\text { Fossil fuels } \\
\text { Natural gas }\end{array}$ & 193 & 194 \\
\hline Oil & 1 & \\
\hline Nuclear power & & 120 \\
\hline Hydropower & & 66 \\
\hline Geothermal power & & 27 \\
\hline Windpower & & 9 \\
\hline Cogeneration & & $\begin{array}{l}94 \\
10\end{array}$ \\
\hline Miscellaneous & & 18 \\
\hline TOTAL & & 729 \\
\hline
\end{tabular}


Table 8

California Utility Electrical Generating Capacity ${ }^{18}$

\begin{tabular}{|c|c|}
\hline $\begin{array}{l}\text { Primary energy } \\
\text { source }\end{array}$ & $\begin{array}{l}\text { Capacity } \\
\text { (GWe) }\end{array}$ \\
\hline Petroleum & 2.16 \\
\hline Gas & 21.97 \\
\hline Water & 13.17 \\
\hline Nuclear & 4.31 \\
\hline Other (principally geothermal) & 2.16 \\
\hline TOTAL & 43.77 \\
\hline
\end{tabular}

Properly added to the utility generating capacity of Table 8 is the combined capacity of nonutility generating facilities which in 1990 was about $9.3 \mathrm{GWe}^{19}$ and about $11 \mathrm{GWe}^{20}$ in 1992. Nonutility generators are self-generators or cogenerators, most of whom are qualified facilities under the Public Utility Regulatory Policies Act of 1978 (PURPA). As such the utilities are required to purchase their output at the utility's "avoided cost", which is the incremental cost that an electric utility would incur to produce or purchase an amount of power equivalent to that purchased from the qualified facilities. Additionally, these facilities are guaranteed back up service from the electric utilities at non-discriminatory rates. Of the 59 billion $\mathrm{kWh}$ generated by the group of nonutilities in $1992,78 \%$ was sold to utilities or other nonutilities; the remainder was used by the generating facility, ${ }^{20}$ which frequently was a manufacturer or food processor. About half of the nonutility generated electricity was produced by burning of fossil fuels; the other half was generated by wood, waste and water, geothermal and wind power.

The state's oldest nuclear reactor, San Onofre Unit 1 owned by Southern California Edison Co. (80\%) and San Diego Gas and Electric Co. (20\%), was shut down in 1992 after 25 years of service. The 436 MWe reactor worked at more than $70 \%$ efficiency for its first 11 years of operation, but since 1980 was inoperative for extended periods as it was retrofitted to meet new seismic and safety standards mandated by the Nuclear Regulatory Commission. ${ }^{21}$ Additional costs to keep it on line were estimated in 1991 to be between $\$ 250$ and $\$ 750$ million. As a consequence it was decided that it was more cost effective to close it and purchase the power out-of-state if necessary. The California Public Utilities Commission ruled that the two utilities owning it would be able to continue to recover the unrecouped portion of their investment in the plant through the rate base.

S. David Freeman, the former general manager of the Sacramento Municipal Utility District (SMUD), is planning to replace the power from the Rancho Seco nuclear plant (916 MW) closed in 1989 with a small cogenerating plant using natural gas, a $50 \mathrm{MW}$ wind farm and a basket of small 
projects promoting energy conservation, e.g. massive tree planting in an effort to cool houses. ${ }^{22}$ In the meantime, the utility is purchasing power.

\section{Alternate Sources of Electricity}

\section{Geothermal}

Geothermal resources are often categorized as a renewable source of energy by analysts. This categorization is one of convenience since in fact geothermal steam and hot water at depth are depletable resources just as oil and gas. The reality of that has been brought home forcibly in California where production at The Geysers, the world's largest geothermal field, has been in steep decline after 20 years of steady growth. To a degree the decline in electrical production at The Geysers was slowed by changes in field production and injection practices in 1992; however it is anticipated to continue. Taking all of California's geothermal fields into account activity (Table 9) was at 1991 levels.

Table 9

\section{Principal Geothermal installations in California (1992) ${ }^{11}$}

Field

$$
\begin{aligned}
& \text { Gross installed } \\
& \text { capacity (MWe) }
\end{aligned}
$$$$
19911992
$$

Coso Hot Springs

East Mesa

The Geysers

Heber

Mono-Long Valley

Salton Sea

Wendell-Amedee

Total
$260 \quad 260$

$130 \quad 130$

19001900

$52 \quad 52$

$40 \quad 40$

$240 \quad 240$

$3 \quad 3$
26252625
Steam/fluid production

(billions of kilograms)

\section{Solar electricity}

$1991 \underline{1992}$

$46.6 \quad 41.2$

$91.9 \quad 97.6$

89.788 .5

$29.2 \quad 29.5$

$24.5 \quad 24.6$

$77.7 \quad 78.0$

$8.2 \quad 8.5$

The use of solar energy in the state is principally to produce hot water in residential and commercial applications. Most of these installations are unmonitored as are small photo voltaic generators, and their collective contribution to the State's energy balance is largely unknown.

All solar electrical installations of any size, e.g. $>100 \mathrm{MW}$, in the U.S. are experimental in nature. Noteworthy are KJC Operating Company's five small solar thermal electric power plants at Kramer Junction, Mojave Desert. These plants, collectively rated at $150 \mathrm{MW}$, focus the sun's direct radiation with long, trough-like mirrors or "parabolic troughs" which carry pipes with heat 
absorbing fluid. In 1992 they registered a 25\% diminution of normal radiation due to the eruption of Mt. Pinatubo in the Philippines in June 1991 and to an increased local cloud-cover. ${ }^{23}$

There are several experimental solar installations under development by the utilities in the state and others have been announced. For example, a Davis, CA group including the Pacific Gas and Electric Company has established a test site to demonstrate the potential for utility-scale applications of photo voltaics. The project calls for building a 200-500 MW solar electric system. ${ }^{24}$

\section{Windpower}

California's windpower industry represents $95 \%$ of the installed capacity in the U.S. and about $70 \%$ of the world's windpower generating capacity. ${ }^{25}$ In 1992 wind installations produced 2.7 billion kilowatt hours of electricity of the 213 billion kilowatt hours consumed in the state. The California Energy Commission equates the output to the annual needs of 450,000 typical California homes based on average consumption of $500 \mathrm{kWh}$ per month. While this is impressive, it should be remembered in assessing this contribution to the energy demand in the state that windpower is not a steady source of supply year-round or even over a 24 hour period. Hence by itself it can not meet the daily or monthly demands of 450,000 homes. In 1992 about $11 \%$ of electricity from windpower was delivered during peak demand; about 25\% "mid-peak", $46 \%$ "off peak" and $17 \%$ "super off peak". 25 Almost three-quarters of wind generated electricity is produced between May and September.

For the first time since 1983 when windpower began to play a role in the State's energy picture both installed capacity and the number of operating turbines fell from the previous year's highs (Table 10). The explanation lies in part in the expiration of long-term interim standard offer contracts with favorable rates. ${ }^{25}$ This in turn resulted in a sharp decline in new turbine installations replacing the many that have reached their useful life span. An additional explanation for the declines is in the failure of one operator with an estimated capacity of $21 \mathrm{MW}$ to report. ${ }^{25}$

The statewide average annual capacity factor also fell in 1992 primarily because of declines at the Altamont field, the oldest producing area in the State. Some $206 \mathrm{MW}$ of old capacity there recorded only an $8 \%$ average capacity factor. The capacity factor is still considered to be a strong indicator of wind project performance. Only operating turbines are used to calculate the factor so that performance results are not skewed by non-operational capacity. For new turbines only onehalf of new capacity is included on the calculation for the first quarter of operation. The theoretical annual average is upwards of $30 \%$, and at least one installation (San Gorgonio Farms) reached $33 \%$ in 1992.25

In 1992 a Danish consortium (consisting primarily of Vestas-Danish Wind Technology $\mathrm{A} / \mathrm{S}$ ) proposed to demonstrate advances in wind technology widely used in Europe by building 20 30 100-foot windmills in the breakwater at the Cabrillo Beach fishing pier in San Pedro. ${ }^{26}$ Local 
inhabitants were not enthusiastic despite the fact that the project claimed to save 70,000 barrels of oil and eliminate 10,000 pounds of air pollutants. More important in terms of receiving a permit from the California Coastal Commission is the impact of the windmills on the brown pelicans that roost near the site. Windmills in other parts of the state have taken heavy toll of local raptors and other large birds.

Table 10

Windpower installations in California as of January 125

Location

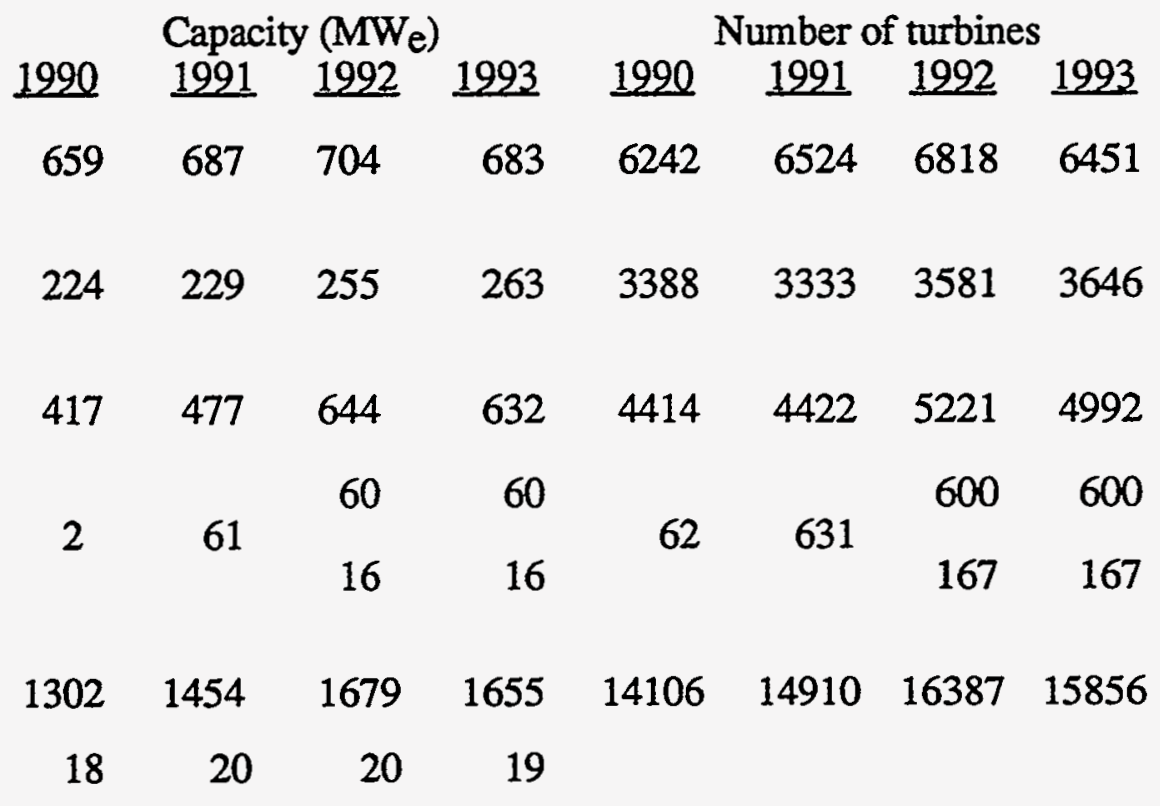

Altamont Pass area, 45 miles east of San Francisco

San Gorgonio Pass, Riverside Co. near Palm Springs

Tehachapi Pass, Kern Co.

Carquinez Strait, Solano Co.

Pacheco Pass, San Benito Co.

TOTAL

Capacity Factor*

*Capacity factor is defined as the ratio of actual energy output to the amount of energy a project would produce if it operated at full rated power for 24 hours per day within a given time period. 


\section{APPENDIX A}

Energy balance for 1992 (Fig. 1)

\section{SUPPLY}

Electrical Imports

Wind

Hydro

Cogenerated electricity (fuels included

in oil and gas supplies below)

Geothermal

Nuclear

Miscellaneous electricity

Natural gas

Include: unaccounted for gas and

net storage additions

Coal

Petroleum

Total

Less exports

$\left(10^{12} \mathrm{Btu}\right)$
331
9
73

150

375

18

2132

70

63

4124

$-399$

6876

2948

988

1292

668

250

3773

423

430

2002

788

255

7

123

Out-of-state elec. generation

130 and transmission losses

Cogeneration (included in Total industrial) 


\section{APPENDIX B}

Data Sources for California Energy Supply (1992)

Production

Crude Oil including Federal

Offshore and Lease Condensate

Associated and Non associated

Natural Gas (marketed, dry)

Electric Utility Fuel Data

Electrical Generation

Oil, gas, hydro, nuclear,

Wind

Cogeneration

Imports

Natural Gas

Foreign

Domestic

Crude Oil

Foreign and Domestic

Oil Products

Foreign and Domestic

Coal

Electrical Power

Net Exchange

Coal

Exports

Oil Products

Foreign and Domestic

(not including bunkering fuel

supplied at California ports)
Source

Ref. 11.

Ref. 27, Table 48, Summary Statistics for Natural Gas - California.

Ref. 28, Table 19, Consumption of Petroleum to Produce Electricity;

Ref. 27, Table 48.

Ref. 28, Tables 13,

Net Generation from Electric Utilities by energy source

Ref. 25.

Andrea Gough, California Energy

Commission, personal communication, March 1, 1994..

Ref. 27, Table 9.

Ref. 27, Table 48.

Ref. 29, Table 1-A, California

Petroleum Summary.

Ref. 29, Table A-1, California Fuels

Market Petroleum Activity.

Ref. 30, Table 46, Coal Consumption by Census Division and State.

Andrea Gough, California Energy Commission, personal communication, March 1, 1994.

Ibid.

Ref. 29, Table A-1. 
Data Sources for California End Uses (1992)

Net Storage

Natural Gas

Unaccounted for Natural Gas

Transportation

Crude Oil

Gasoline, Aviation and Jet fuels

Taxable Diesel Fuel

(for public highways)

Vessel Bunkering

(includes international bunkering)

Rail Diesel

Military Use

Natural Gas

Pipeline fuel

Industrial. Government, Agriculture, etc.

Natural Gas

(includes lease and plant

fuel)

Coal

Electricity

Crude Oil

Non Energy Applications

Crude Oil and LPG

Asphalt

Petrochemical Feedstock

Waxes, Lubricating oils, Medicinal uses, Cleaning
Ref. 27, Table 48.

Ref. 27, Table 48.

Ref. 29, Table 1-A.

Ref. 31, Table 4, Sales for

Transportation Use: Distillate Fuel Oil

End Use, 1991.

Ref. 31 , Table $4 \& 5$.

Ref. 31. Table 4.

Ibid.

Ref. 27, Table 48.

Ref. 27, Table 48.

Ref. 30, Table 24.

Ref. 28, Table 26 Sales of

Electricity to Ultimate Consumers by

Class of Service, Year to date.

By Difference.

Ref. 32

Ref. 33, Table 45 (estimate) \& Ref. 34, Table 12

Quarterly Oil Reports 1992 


\section{APPENDIX C - Continued}

Residential and Small Commercial

Natural Gas

Crude Oil and Other Oils

(kerosene, residual, and distillate)

LPG

Miscellaneous "Off highway" Diesel

Electricity
Ref. 27, Table 48.

Ref. 31, Table 6, Sales of Kerosene by End Use; Table 5, Sales of Residual Fuel Oil by End Use; Table 4, Sales of Distillate Fuel Oil by End Use.

Ref. 33, Tables 43 \& 44 \& Ref. 34, Table 12.

Ref. 31, Table 4.

Ref. 28, Table 26 


\section{APPENDIX D}

\section{Conversion Units}

Energy Source

\section{Electricity}

Coal 22.6 per short ton

Natural Gas

Crude Oil

Fuel Oil

Residual

Distillate, including diesel

Gasoline and Aviation Fuel

Kerosene

Asphalt

Road Oil

Synthetic Rubber and Miscellaneous

LPG Products
Conversion factor, $10^{6}$ Btu

3.415 per million Wh

1.05 per Mcf

5.80 per barrel

6.287 per barrel

5.825 per barrel

5.248 per barrel

5.67 per barrel

6.636 per barrel

6.636 per barrel

4.01 per barrel

Assumed Conversion Efficiencies of Primary Energy Supply

Electric Power Generation

Hydro Power

Coal

Geothermal

Oil and Gas

Uranium

Transportation Use

Residential/Commercial Use

Industrial Use 


\section{REFERENCES}

1. a) E. Behrin and R. Cooper, California Energy Outlook, Lawrence Livermore Laboratory Report, UCRL-51966, Rev. 1 (1976).

b) I. Y. Borg, California Energy Flow in 1976, 1977 Lawrence Livermore Laboratory Report, UCRL-52451 (1978) and UCD-18221 (1979) respectively.

c) A. L. Austin and S. D. Winter, U.S. Energy Flow Charts for 1950, 1970, 1980, 1985 and 1990, Lawrence Livermore Laboratory Report, UCRL-51487 (1973).

d) I. Y. Borg and C. K. Briggs, California Energy Flow in 1978, 1979, 1980, 1981, 1982 , 1983, 1985, 1986, 1987, 1988, 1989, 1990, 1991 Lawrence Livermore Laboratory Reports, UCID-18760 (1980), UCID-18991 (1981), 18991-80 (1982), 18991-81 (1983), 18991-82 (1983), 18991-83 (1984), 18991-85 (1986), 18991-86 (1987), 18991-87 (1989), 18991-88 (1989), 18991-89 (1991), 18991-90(1992), 18991-91(1993) respectively.

e) I. Y. Borg and C. K. Briggs, "California's Energy Supply and Demand in 1984," Annual Review of Energy 11. p. 209-28 (1986).

2. I. Y. Borg and C. K. Briggs, U.S. Energy Flow - 1992, Lawrence Livermore Laboratory Report, UCRL-ID 19227-92 (October 1993).

3. L. Harper, "California economy increasingly shows signs of dragging down U.S. recovery," The Wall Street J. p. A2 (January 29, 1993).

4. T. Munroe, "Is the shine off the Golden State?" The Commonwealth LXXXVI \#6 p. 83 (February 10, 1992).

5. California Economic Indicators, California Department of Finance, Sacramento, CA, p. 9 (January-February 1993).

6. California Statistical Abstract - 1993, California Department of Finance, Sacramento, CA, Table I-3, Table I-4 (November 1993).

7. Travel and Related Factors in California - Annual Summary 1992, California Department of Transportation, Sacramento, CA (1993).

8. M. L. Wald, "California's Pied Piper of Clean Air," The New York Times, p. F1 (September 13, 1992).

9. S. La Rue, "It may be car pools, buses for $35 \%$ of us," The San Diego Union, p. Al (November 13, 1992).

10. California Public Utilities Commission - Annual Report 1992-1993, San Francisco, CA (1993).

11. 78th Annual Report of the State Oil and Gas Supervisor - 1992, California Department of Conservation, Division of Oil and Gas, Publ. No. PRo6, Sacramento, CA (1993). 
12. J. Pelline, "Chevron wins fight to ship crude oil," San Francisco Chronicle, B1, (July 14, 1993).

13. "Alaska-California tanker route to be at least 50 miles offshore," Oil and Gas J. p. 26 (June 8, 1992).

14. G. Lucas, "Wilson signs bills to expand drilling bans," San Francisco Chronicle, (October 1, 1992).

15. "Kern River natural gas pipeline commissioned," p. 28, Oil and Gas J. (March 16, 1992).

16. B. White, "New Pipeline Construction - Status Report Year-End 1992," Gas Energy Review 21 \#3, p. 2-13 (March 1993).

17. "Canada energy panel tightens restrictions on new gas exports," The Wall Street J. p. A 18, (June 25, 1992).

18. Inventory of Power Plants in the United States 1992, U.S. Department of Energy, Washington, DC, DOE/EIA-0095(92) (October 1993).

19. L. Prete, J. Gordon and B. Williams, "Nonutility power producers," Electric Power Monthly, U.S. Department of Energy DOE/EIA-0226 (92/04) (April 1991).

20. Electric Power Annual - 1992, U.S. Department of Energy, Washington, DC., EOE/EIA0348(92) (January 1994). Estimated from the total installed capacity of nonutility generators in the Pacific region (Table 75) using Califomia's share of gross generation in the Pacific region $(88.4 \%)$ (Table 82 ) as a guide.

21. T. Gorman, "Oldest nuclear generator in California to shut down," Los Angeles Times, p. B3 (August 13, 1992).

22. D. Kaplan, "Freeman's energy diet: efficiency, renewables," The Energy Daily, 20, p. 1 (December 11, 1992).

23. "Pinatubo, weird weather challenge California's wind and solar thermal electric industries," Energy, Economics and Climate Change, Cutter Information Corp, p. 2 (July 1992).

24. J. Pelline, "Futuristic fuel firms - alternative energy thrives in Bay Area," San Francisco Chronicle, p. C-1 (March 18, 1993).

25. Wind Project Performance - 1992 Summary, Committee Report P500-93-002, California Energy Commission, Sacramento, CA (June 1993).

26. L. Richardson, "Windmill plan could re-energize an industry," Los Angeles Times, p. B-3 (October 7, 1992).

27. Natural Gas Annual - 1992, vol. 1, U.S. Department of Energy, Washington, DC, DOE/EIA-031(92) (November 1993). 
28. Electric Power Annual — 1992, U.S. Department of Energy, Washington, DC, DOE/EIA0348(92) (January 1994).

29. Quarterly Oil Report, 4th Quarter 1992, California Energy Commission, Sacramento, CA (May 1993).

30. Quarterly Coal Report, 4th Quarter 1992, U.S. Department of Energy, Washington, DC, DOE/EIA-0121 (92) (May 1993)

31. Fuel Oil and Kerosene Sales 1992, U.S. Department of Energy, Washington, DC, DOE/EIA-0535(92) (October 1993)

32. Asphalt Usage 1992, United States and Canada, Asphalt Institute, Lexington KY (May 1993).

33. State Energy Data Report - Consumption Estimates (1991), U.S. Department of Energy, Washington, DC, DOE/EIA-0214(91) (May 1993).

34. Petroleum Supply Annual - 1992, Vol. 1, U.S. Department of Energy, Washington, DC DOE/EIA-0340(92/1). 